\title{
Evaluation of Heavy Metals Pollution Status of the Groundwater around Riruwai Mining Area, Kano State, Nigeria
}

\author{
H. Badamasi, U.F. Hassan, H. M. Adamu, and N. M. Baba
}

\section{ABSTRACT}

\begin{abstract}
The aim of this study was to investigate the heavy metals pollution status of the groundwater of Riruwai mining area, Kano State, Nigeria. A total of 31 groundwater samples were collected from five sampling locations which include: underground mining site (RGWI), tap water, (RGW2), surface mining ponds (RGW3), borehole (RGW4) and the well water samples (RGW5) during the dry and rainy seasons. The concentrations of seven heavy metals (As, $\mathrm{Cd}, \mathrm{Cr}, \mathrm{Hg}, \mathrm{Mn}, \mathrm{Pb}$ and $\mathrm{Zn}$ ) and some physical parameters (pH, EC, and TDS) were determined using Atomic Absorption Spectrometer and Deluxe Water and Soil Analysis Kit respectively. The results of the analysis revealed that $\mathrm{pH}, \mathrm{EC}$ and TDS were within the desirable limits recommended by WHO and NSDWQ in all sampling locations except in RGW1 and RGW3 for both seasons. The concentrations of heavy metals $\left(\mathrm{mg} / \mathrm{dm}^{3}\right)$ ranged as follow: As (ND to 0.15), Cd (ND to 0.1), $\mathrm{Cr}$ (ND to 0.25), $\mathrm{Hg}$ (ND to 0.09$), \mathrm{Mn}(0.12$ to 0.66$), \mathrm{Pb}(0.003$ to 0.06$)$ and $\mathrm{Zn}(2.29$ to 11.75), and $\mathrm{As}(0.005$ to 020$), \mathrm{Cd}(0.001$ to 0.15$), \mathrm{Cr}(0.001$ to $0.17), \mathrm{Hg}$ (ND to 0.14$), \mathrm{Mn}(0.16$ to 0.92$), \mathrm{Pb}(0.007$ to 0.09$)$ and $\mathrm{Zn}(2.85$ to 14.05) during the dry and rainy seasons respectively. The heavy metals concentrations changed along with the sampling sites in decreasing order of RGW1 > RGW2 > RGW3 > RGW4 > RGW5 in both seasons. The concentrations of all heavy metals were above the desirable limits recommended by WHO and NSDWQ during both seasons except well water samples (RGW5) and some few locations where the heavy metals were not detected. Therefore, it is recommended that water resources of the Riruwai mining area should be monitored closely, and more efforts should be made to reduce heavy metals concentrations level, particularly $\mathrm{As}, \mathrm{Cd}, \mathrm{Cr}$ and $\mathrm{Zn}$.
\end{abstract}

Keywords: Atomic Absorption Spectrometer, Concentrations, Heavy metals, Riruwai

\section{INTRODUCTION}

Groundwater is among the most significant and essential resources that occurs in a permeable geologic formations known as aquifers [1]. Approximately 2 billion people across the globe depend on groundwater as the main source of water for human consumption and agricultural practices [2]. Rapid population growth, industrial development, agricultural practices, and mining activities has contributed to the groundwater overutilization for many years, placing unprecedented pressure on global groundwater supplies [3]. Mining activities are major anthropogenic activities causing water pollution and they are well known for their deleterious effects on the groundwater [4]. Mine tailings and other mining-related operations are the major source of contaminants, mainly of heavy metals in water. Previous studies have shown that the extensive mining activities have deleterious effects on the groundwater resources due to the release of toxic metals from various environmental components such as soils, sediments, surface water and groundwater [5]. Heavy metals are of serious importance to human health and ecosystem owing to their toxic effects and
Published Online: May 28, 2021

ISSN: $2684-446 \mathrm{X}$

DOI :10.24018/ejgeo.2021.2.3.140

\section{H. Badamasi *}

Department of Chemistry, Federal University Dutse, Jigawa State, Nigeria

(e-mail: hamza.badamasi@fud.edu.ng)

\section{U. F. Hassan}

Department of Chemistry, Abubakar Tafawa Balewa University, Bauchi State, Nigeria

(e-mail: ufhassan2007@gmail.com)

H. M. Adamu

Department of Chemistry, Abubakar Tafawa Balewa University, Bauchi State, Nigeria

(e-mail: hmadamu@atbu.edu.ng)

N. M. Baba

Department of Chemistry, Federal University of Lafia, Nasarawa State, Nigeria.

(email: n.m.baba@ ${ }^{@}$ science.fulafia.edu.ng)

*Corresponding Author persistence in the environment [6]. During mining and smelting processes, heavy metals are usually discharged from mining areas by erosion, weathering, and leaching into nearby soil, surface, and groundwater [7]. A study conducted by Giri and Singh [8] affirmed that $50 \%$ of the groundwater samples were highly polluted with respect to heavy metals like $\mathrm{Cu}, \mathrm{Ni}, \mathrm{Co}, \mathrm{Cr}, \mathrm{Mn}$ and $\mathrm{Pb}$ in the proximity of copper mining region. A groundwater of Udege Mbeki Mining District, North-Central, Nigeria was reported by Okegye and Gajere [9] to be contaminated with heavy metals. The present study sought to investigate the groundwater quality status related to heavy metals pollution in the mining area of Riruwai, Kano State, Nigeria. The research would provide baseline data for policy makers and the general public on the heavy metals metal pollution status of the study area for future environmental monitoring.

\section{MATERIALS AND METHODS}

\section{A. Materials}

In preparing the solutions, analytical grade reagents were used throughout the study without further purification. All 
glass and plastic wares were soaked overnight in $10.00 \%$ (v/v) nitric acid, washed three times with distilled water and finally three times with deionized water. The wares were oven dried at $50.00-60.00{ }^{\circ} \mathrm{C}$ [10]. Angstrom Atomic Absorption Spectrometer with the model AAS320 was used for the determination of heavy metals in the groundwater samples.

\section{B. Methods}

\section{Description of the study area}

Riruwai, the headquarters of Doguwa Local Government Area is located in the Southern part of Kano State, Northern Nigeria. It lies between latitude $10^{\circ} 43^{\prime} 97^{\prime}$ ' $\mathrm{N}-10^{\circ} 45^{\prime} 01$ 'N and longitude $8^{\circ} 43$ ' 3 'E - $8^{\circ} 47^{\prime} 39^{\prime \prime}$ E covering an area of $129 \mathrm{~km}^{2}$ (Fig. 1). Riruwai has the highest elevation in the whole of Kano having an average height of $1100 \mathrm{~m}$ above the sea level. It was reported to have a contour value greater than $580 \mathrm{~m}$ and slope of greater than $18^{\circ}$ above sea level. The Köppen's climate classification categorized the climate as tropical savanna [11]. Riruwai is among the younger granite complexes in Nigeria. It is situated amidst the assemblage of metamorphic and calc-alkaline meta-igneous rocks that subsequently changed from Precambrian to Cambrian ages [12].

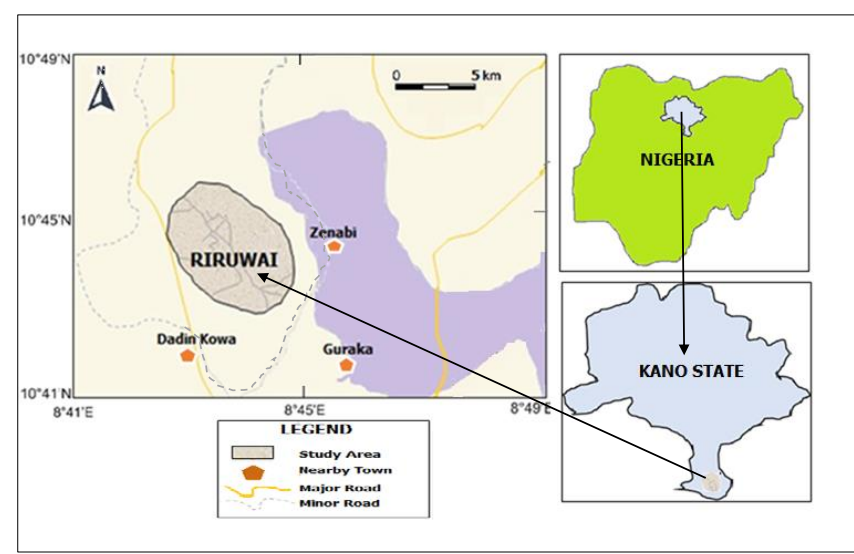

Fig. 1. Map showing the study Area.

\section{Sampling of the groundwater samples}

Sampling was performed in February (dry season) and August (rainy season) of 2020 to get an idea of the seasonal variations of the heavy metal concentrations. A total of 31 groundwater samples were collected from five sampling sites which include underground mining pond (RGWI), tap water (RGW2), mining ponds (RGW3), borehole (RGW4) and the well water (RGW5). All the samples were collected in polyethylene bottles which were pre-washed with $20.00 \%$ of $\mathrm{HNO}_{3}$ and deionized water, except for the determination of $\mathrm{Hg}$ where borosilicate glass bottles were used to minimize $\mathrm{Hg}^{2+}$ loss and contamination as reported by Bravo et al. [13]. During sampling, two bottles were filled with water from each sampling site and then filtered. A few drops of $65.00 \%$ of $\mathrm{HNO}_{3}$ were added to one bottle of water samples (bringing the $\mathrm{pH}$ of the samples below 2.00) to minimize precipitation and adsorption onto container walls [14] and was used to determine heavy metals concentrations. The second bottle was not acidified and was used to measure $\mathrm{pH}$, electrical conductivity (EC) and total dissolved solids (TDS). To get constant $\mathrm{pH}$ and EC, the samples were collected after $15 \mathrm{~min}$ of pumping of the samples. The pH, EC and TDS were measured on the spot using Deluxe Portable Water and Soil Analysis Kit (Model 1024 G). The samples were placed in an ice-box and transported to the laboratory for further analysis.

3. Concentration and digestion of the groundwater samples

A $500.00 \mathrm{~cm}^{3}$ of the filtered water sample (in a $1000 \mathrm{~cm}^{3}$ beaker) was placed on a hot plate and evaporated to $50.00 \mathrm{~cm}^{3}$. The sample was allowed to cool and transferred into a $250 \mathrm{~cm}^{3}$ beaker. $10.00 \mathrm{~cm}^{3}$ of concentrated $\mathrm{HNO}_{3}$ was added and the resulting solution was heated slowly at $80{ }^{\circ} \mathrm{C}$ until a clear solution was obtained [14]. Slow heating was done to avoid metal loss due to evaporation. The digested sample was allowed to cool, filtered through Whatman filter paper No. 42, and then transferred into a $100 \mathrm{~cm}^{3}$ volumetric flask. More deionized water was added to the solution to make it up to the mark.

4. Determination of heavy metals in the groundwater samples

The levels of seven heavy metals namely: As, $\mathrm{Cd}, \mathrm{Cr}, \mathrm{Hg}$, $\mathrm{Mn}, \mathrm{Pb}$ and $\mathrm{Zn}$ were analyzed using Angstrom Atomic Absorption Spectrometer Model AAS-320 by selecting a suitable wavelength for each element. Three replicate determinations were run for each sample and the instrument was re-calibrated after analysis of ten samples.

\section{Quality control and statistical analysis}

All samples were analyzed in triplicate. The standard solutions of all heavy metals were prepared by successive dilution of certified standards $\left(1000 \mathrm{mg} / \mathrm{dm}^{3}\right)$ procured from Sigma Aldrich and the calibration curve of each metal was constructed. Blank determinations were carried out to correct any background contamination from reagents, filter papers or other systemic sources of error. All statistical analyses were carried out using SPSS 23.0 (SPSS Inc., Chicago, USA). All graphs were plotted using OriginPro 2016 (Originlab Corporation, USA) software.

\section{RESULTS AND DISCUSSION}

\section{A. Results}

1. Heavy metals concentrations and some physical parameters of the groundwater samples

The mean concentrations of arsenic (As), cadmium (Cd), chromium $(\mathrm{Cr})$, mercury $(\mathrm{Hg})$, manganese $(\mathrm{Mn})$, lead $(\mathrm{Pb})$ and zinc $(\mathrm{Zn})$ and some selected physical parameters $(\mathrm{pH}$, electrical conductivity, and total dissolved solid) were determined respectively in water samples from five different sampling sites (underground mining site, tap water, mining pond, borehole and well water) during the dry and rainy seasons are presented in Tables I and II. 
TABLE I: Levels of Heavy Metals and Some SElected Physical Parameter in the Water SAMPles OF RiRuwai, Kano State during the DRY SEASON

\begin{tabular}{|c|c|c|c|c|c|c|c|}
\hline \multirow{2}{*}{ Parameters } & \multicolumn{5}{|c|}{ Sampling Locations } & \multirow[b]{2}{*}{ WHO } & \multirow[b]{2}{*}{ NSDWQ } \\
\hline & RGWI & RGW2 & RGW3 & RGW4 & RGW5 & & \\
\hline $\mathrm{pH}$ & $5.61 \pm 0.14$ & $6.82 \pm 0.06$ & $5.31 \pm 0.02$ & $6.79 \pm 0.03$ & $6.88 \pm 0.05$ & $6.5-9.5$ & $6.5-8.5$ \\
\hline $\mathrm{EC}(\mu \mathrm{S} / \mathrm{cm})$ & $1500 \pm 9.50$ & $469.00 \pm 5.23$ & $1722.00 \pm 3.00$ & $523.00 \pm 2.08$ & $423.00 \pm 2.52$ & 1400 & 1000 \\
\hline TDS $\left(\mathrm{mg} / \mathrm{dm}^{3}\right)$ & $960.00 \pm 3.61$ & $300.16 \pm 2.11$ & $1102.08 \pm 1.53$ & $314.72 \pm 2.00$ & $270.72 \pm 2.08$ & - & 500 \\
\hline As $\left(\mathrm{mg} / \mathrm{dm}^{3}\right)$ & $0.15 \pm 0.02$ & $0.02 \pm 0.00$ & $0.21 \pm 0.02$ & $0.02 \pm 0.01$ & ND & 0.01 & 0.01 \\
\hline $\mathrm{Cd}\left(\mathrm{mg} / \mathrm{dm}^{3}\right)$ & $0.11+0.00$ & ND & $0.08 \pm 0.01$ & $0.01 \pm 0.007$ & ND & 0.003 & 0.003 \\
\hline $\mathrm{Cr}\left(\mathrm{mg} / \mathrm{dm}^{3}\right)$ & $0.13 \pm 0.01$ & $0.04 \pm 0.01$ & $0.25 \pm 0.03$ & ND & ND & 0.05 & 0.05 \\
\hline $\mathrm{Hg}\left(\mathrm{mg} / \mathrm{dm}^{3}\right)$ & $0.09 \pm 0.03$ & ND & $0.07 \pm 0.01$ & ND & ND & 0.006 & 0.001 \\
\hline $\mathrm{Mn}\left(\mathrm{mg} / \mathrm{dm}^{3}\right)$ & $0.66 \pm 0.02$ & $0.14 \pm 0.03$ & $0.50 \pm 0.01$ & $0.30 \pm 0.01$ & $0.12 \pm 0.01$ & - & 0.2 \\
\hline $\mathrm{Pb}\left(\mathrm{mg} / \mathrm{dm}^{3}\right)$ & $0.06 \pm 0.01$ & $0.007 \pm 0.00$ & $0.08 \pm 0.02$ & $0.04 \pm 0.02$ & $0.003 \pm 0.00$ & 0.01 & 0.01 \\
\hline $\mathrm{Zn}\left(\mathrm{mg} / \mathrm{dm}^{3}\right)$ & $11.73 \pm 2.61$ & $5.26 \pm 0.03$ & $17.43 \pm 0.07$ & $4.88 \pm 0.01$ & $2.29 \pm 0.03$ & - & 3 \\
\hline
\end{tabular}

Values are mean \pm standard deviation $(\mathrm{n}=3)$, ND $=$ Not detected. RGW1 = Underground mining area water samples, RGW2 $=$ Tap water samples, RGW3 = Mining pond water samples, RGW4 = Borehole water samples, RGW5 = Well water samples. WHO = World Health Organization $(2011)$ NSDWQ = Nigerian Standards for Drinking Water Quality (2007)

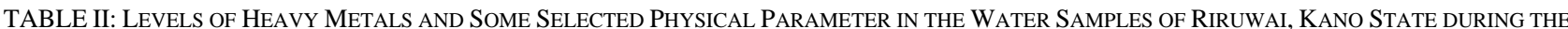
RAINY SEASON

\begin{tabular}{|c|c|c|c|c|c|c|c|}
\hline \multirow{2}{*}{ Parameters } & \multicolumn{5}{|c|}{ Sampling Locations } & \multirow[b]{2}{*}{ WHO } & \multirow[b]{2}{*}{ NSDWQ } \\
\hline & RGWI & RGW2 & RGW3 & RGW4 & RGW5 & & \\
\hline $\mathrm{pH}$ & $5.87 \pm 0.10$ & $7.63 \pm 0.05$ & $5.98 \pm 0.02$ & $7.53 \pm 0.02$ & $7.64 \pm 0.07$ & $6.5-9.5$ & $6.5-8.5$ \\
\hline $\mathrm{EC}(\mu \mathrm{S} / \mathrm{cm})$ & $1700 \pm 11.50$ & $501.00 \pm 1.53$ & $1951.00 \pm 2.51$ & $589.00 \pm 1.88$ & $498.00 \pm 2.56$ & 1400 & 1000 \\
\hline TDS $\left(\mathrm{mg} / \mathrm{dm}^{3}\right)$ & $1088.00 \pm 2.00$ & $320.64 \pm 2.51$ & $1248.64 \pm 2.08$ & $376.96 \pm 2.00$ & $318.72 \pm 2.00$ & - & 500 \\
\hline As $\left(\mathrm{mg} / \mathrm{dm}^{3}\right)$ & $0.20 \pm 0.03$ & $0.03 \pm 0.01$ & $0.35 \pm 0.04$ & $0.04 \pm 0.01$ & $0.005 \pm 0.001$ & 0.01 & 0.01 \\
\hline $\mathrm{Cd}\left(\mathrm{mg} / \mathrm{dm}^{3}\right)$ & $0.15+0.01$ & $0.009 \pm 0.00$ & $0.11 \pm 0.01$ & $0.02 \pm 0.04$ & $0.001 \pm 0.00$ & 0.003 & 0.003 \\
\hline $\mathrm{Cr}\left(\mathrm{mg} / \mathrm{dm}^{3}\right)$ & $0.17 \pm 0.03$ & $0.06 \pm 0.01$ & $0.32 \pm 0.05$ & $0.008 \pm 0.00$ & $0.001 \pm 0.00$ & 0.05 & 0.05 \\
\hline $\mathrm{Hg}\left(\mathrm{mg} / \mathrm{dm}^{3}\right)$ & $0.14 \pm 0.03$ & ND & $0.09 \pm 0.00$ & $0.003 \pm 0.00$ & ND & 0.006 & 0.001 \\
\hline $\operatorname{Mn}\left(\mathrm{mg} / \mathrm{dm}^{3}\right)$ & $0.92 \pm 0.05$ & $0.17 \pm 0.01$ & $0.73 \pm 0.03$ & $0.49 \pm 0.05$ & $0.16 \pm 0.03$ & - & 0.2 \\
\hline $\mathrm{Pb}\left(\mathrm{mg} / \mathrm{dm}^{3}\right)$ & $0.09 \pm 0.03$ & $0.03 \pm 0.02$ & $0.10 \pm 0.04$ & $0.06 \pm 0.01$ & $0.007 \pm 0.001$ & 0.01 & 0.01 \\
\hline $\mathrm{Zn}\left(\mathrm{mg} / \mathrm{dm}^{3}\right)$ & $14.05 \pm 0.08$ & $7.01 \pm 0.03$ & $20.03 \pm 0.06$ & $5.90 \pm 0.03$ & $2.85 \pm 0.02$ & - & 3 \\
\hline
\end{tabular}

Values are mean \pm standard deviation $(n=3), N D=$ Not detected, RGW1 = Underground mining area water samples, RGW2 = Tap water samples, RGW3 = Mining pond water samples, RGW4 = Borehole water samples, RGW5 = Well water samples. WHO = World Health Organization (2011), NSDWQ = Nigerian Standards for Drinking Water Quality (2007)

\section{B. Discussion}

\section{Physical parameters of the groundwater samples}

The $\mathrm{pH}$ of the water is a very important water quality parameter, and its measurement is crucial in evaluating water quality. This is due to the fact that $\mathrm{pH}$ regulates the solubility of hazardous metals in the aquatic ecosystem, which can have a severe impact on aquatic organisms and human health [15]. The $\mathrm{pH}$ of the groundwater as depicted in Tables I to II ranged from 5.31 (mining pond) to 6.88 (well water), with 5.61 (underground mining site), 6.79 (borehole) and 6.82 (tape water) falling in between the lowest and highest $\mathrm{pH}$ values during the dry season. During the rainy season, the $\mathrm{pH}$ values varied from 5.87 (underground mining site) to 7.64 (well water). The $\mathrm{pH}$ of 5.98 (mining ponds), 7.53 (boreholes) and 7.63 (tape water) fell in between the lowest and highest values. Generally, the $\mathrm{pH}$ values of all sampling locations were higher during the rainy season and decreased in the order of well water $>$ tap water $>$ borehole $>$ underground mining site $>$ mining pond. Mining pond location was having lowest $\mathrm{pH}$ (more acidic) value while the highest $\mathrm{pH}$ (slightly alkaline) value was recorded in the well water samples for both seasons. The decreased $\mathrm{pH}$ values observed at all sampling sites during the dry season is most likely due to dissolved mineral ions generated by evapotranspiration. Likewise, the increase in $\mathrm{pH}$ during the rainy season might be attributed to the diluting action of dissolved ions [16]. The $\mathrm{pH}$ values in all the samples were within the permissible limits for drinking water recommended by the WHO and the NSDWQ for both seasons except for underground mining site and mining pond. These results were in good agreement with those reported by Singh and Kamal [1] and Rahman et al. [17]. The low $\mathrm{pH}$ values in underground mining sites and mining ponds may be due to the formation of sulfuric acid from the oxidation of pyrite in the ore [18].

Electrical conductivity (EC) is a measure of an ability of substances to conduct electricity. Higher EC values indicates the enrichment of dissolve ions and pollution load in the groundwater [19]. The EC values ranged from $423.00 \mu \mathrm{S} / \mathrm{cm}$ (well water) to $1722.00 \mu \mathrm{S} / \mathrm{cm}$ (mining pond), with $469.00 \mu \mathrm{S} / \mathrm{cm}$ (tape water), $523.00 \mu \mathrm{S} / \mathrm{cm}$ (borehole) and $1500.00 \mu \mathrm{S} / \mathrm{cm}$ (underground mining site) fell in between the lowest and highest EC values during dry season. During the rainy season, the EC values ranged from $498.00 \mu \mathrm{S} / \mathrm{cm}$ (well water) to $1951.00 \mu \mathrm{S} / \mathrm{cm}$ (mining pond). The EC of $501.00 \mu \mathrm{S} / \mathrm{cm}$ (tape water), $589.00 \mu \mathrm{S} / \mathrm{cm}$ (borehole) and $1700.00 \mu \mathrm{S} / \mathrm{cm}$ (underground mining site) fell in between the extreme values. The findings of this research revealed that EC values decreased during the dry season and increased during the rainy season. This was consistent with the findings of Silas et al. [15]. All EC values were within the threshold values recommended by WHO and NSDWQ except in underground mining water and mining pond water samples. The highest EC value of $1953.51 \mu \mathrm{S} / \mathrm{cm}$ was found at the mining pond in the rainy season, while the lowest EC value of $420.48 \mu \mathrm{S} / \mathrm{cm}$ was recorded in the well water. The higher EC values in underground mining site and mining pond might be due the presence of excess ions in the water [20]. According to Abida and Harikrishna [21] the conductivity values below $50.00 \mu \mathrm{S} / \mathrm{cm}$ are regarded as low, while those between $50.00-600.00 \mu \mathrm{S} / \mathrm{cm}$ are said to be medium and values above $600.00 \mu \mathrm{S} / \mathrm{cm}$ are considered to be high. In this 
study, all the water samples were below $600.00 \mu \mathrm{S} / \mathrm{cm}$ except for underground mining site and mining pond which were above $600.00 \mu \mathrm{S} / \mathrm{cm}$, indicating high conductivity high conductivity.

Total dissolved solids (TDS) are the inorganic ions and smaller quantities of organic matter that exists as solution in water. TDS values varied from $270.72 \mathrm{mg} / \mathrm{dm}^{3}$ (well water) to $1102.08 \mathrm{mg} / \mathrm{dm}^{3}$ (mining pond), with $300.16 \mathrm{mg} / \mathrm{dm}^{3}$ (tap water), $314.72 \mathrm{mg} / \mathrm{dm}^{3}$ (borehole) and 960.00 (underground mining site) falling in between the lowest and highest values of TDS determined during the dry season. During the rainy season, the TDS values spread from $318.72 \mathrm{mg} / \mathrm{dm}^{3}$ (well water) to $1951.00 \mathrm{mg} / \mathrm{dm}^{3}$ (mining pond), with $320.64 \mathrm{mg} / \mathrm{dm}^{3}$ (tape water), $376.96 \mathrm{mg} / \mathrm{dm}^{3}$ (borehole) and $1088.00 \mathrm{mg} / \mathrm{dm}^{3}$ (underground mining site) fell in between the lowest and highest TDS values. The highest value of TDS was found in the rainy season at mining pond while the lowest was recorded at the well water. All values of TDS were within the permissible limit suggested by NSDWQ with the exception of water samples from underground mining site and mining pond in both dry and rainy seasons. Zhu et al. [22] reported similar results when they studied the effects of mining activities on groundwater hydrochemistry and heavy metals migration in the Yangtze Metallogenic Region, Eastern China.

\section{Levels of heavy metals in the groundwater samples}

The concentrations of arsenic (As) ranged from ND (well water) to $0.21 \mathrm{mg} / \mathrm{dm}^{3}$ (mining pond) with $0.02 \mathrm{mg} / \mathrm{dm}^{3}$ (tap water and borehole) and $0.15 \mathrm{mg} / \mathrm{dm}^{3}$ (underground mining site) falling in between extreme concentrations during the dry season. During rainy season, the concentration of As varied between $0.35 \mathrm{mg} / \mathrm{dm}^{3}$ in the mining pond location and 0.005 $\mathrm{mg} / \mathrm{dm}^{3}$ in the well water. The As concentration of 0.003 $\mathrm{mg} / \mathrm{dm}^{3}$ (tap water), $0.004 \mathrm{mg} / \mathrm{dm}^{3}$ (borehole) and 0.20 $\mathrm{mg} / \mathrm{dm}^{3}$ (underground mining site) were in the middle of the range. The higher concentrations levels of As were found during the rainy season with mining pond site having the highest As concentration while the lowest concentration was detected at well water samples. Similar results were reported by Obasi and Akudinobi [23] when they studied the levels of heavy metals in water resources of lead-zinc mining communities of Abakaliki, Southeast Nigeria. The concentrations of As were above allowable limits recommended by WHO and NSDWQ in all sampling locations and for all seasons except in the well water. This indicated that the ground water has been polluted by As. Lower levels of As exposure have been linked to nausea, vomiting, decreased erythrocyte, leukocyte production and irregular heartbeats, whilst long-term exposure has been connected to the development of skin lesions, internal malignancies, lung illness, peripheral vascular disease, hypertension and cardiovascular disease [24].

The concentration of cadmium $(\mathrm{Cd})$ ranged from ND (well water and tap water) to $0.11 \mathrm{mg} / \mathrm{dm}^{3}$ (underground mining site) with $0.01 \mathrm{mg} / \mathrm{dm}^{3}$ (borehole) and $0.08 \mathrm{mg} / \mathrm{dm}^{3}$ (mining pond) falling in between the lowest and highest concentrations of $\mathrm{Cd}$ for the period of dry season. During the rainy season, the concentration of $\mathrm{Cd}$ spread from 0.001 $\mathrm{mg} / \mathrm{dm}^{3}$ (well water) to $0.15 \mathrm{mg} / \mathrm{dm}^{3}$ (underground mining site) with $0.009 \mathrm{mg} / \mathrm{dm}^{3}, 0.02 \mathrm{mg} / \mathrm{dm}^{3}$ and $0.11 \mathrm{mg} / \mathrm{dm}^{3}$ falling in between the lowest and highest concentrations. The concentrations of $\mathrm{Cd}$ in all sampling sites were above WHO and NSDWQ acceptable range except in tap water and well water samples. High levels of $\mathrm{Cd}$ in mining pond, underground mining site and borehole could be linked to the weathering and subsequent dissolution of the chalcopyrite and pyrite ores in the area [23]. The concentrations of chromium $(\mathrm{Cr}$ ) ranged from ND (well water and borehole) to $0.25 \mathrm{mg} / \mathrm{dm}^{3}$ (mining pond) with $0.04 \mathrm{mg} / \mathrm{dm}^{3}$ and $0.13 \mathrm{mg} / \mathrm{dm}^{3}$ falling between the lowest and highest concentrations in the dry season. During the rainy season, the concentration of $\mathrm{Cr}$ ranged from $0.001 \mathrm{mg} / \mathrm{dm}^{3}$ (well water) to $0.32 \mathrm{mg} / \mathrm{dm}^{3}$ (mining pond). The $\mathrm{Cr}$ concentrations of $0.008 \mathrm{mg} / \mathrm{dm}^{3}, 0.06 \mathrm{mg} / \mathrm{dm}^{3}$ and $0.17 \mathrm{mg} / \mathrm{dm}^{3}$ lied in between the extreme concentrations level of $\mathrm{Cr}$. The concentration of $\mathrm{Cr}$ in borehole and well water was within the WHO and NSDWQ permissible limits for all seasons whereas the concentration of $\mathrm{Cr}$ in mining pond and underground mining site were above allowable limit. In tap water sample, the concentration of $\mathrm{Cr}$ was above the WHO and NSDWQ recommended limit during the rainy season and below the limit during the dry season. This was in good agreement with results reported by Prasad et al. [25]. Cr has reported to cause anemia, irritations and ulcers in the small intestine and stomach, damage sperm and neurological effects [26].

The concentration of mercury $(\mathrm{Hg})$ ranged from ND (tap water, borehole and well water) to $0.09 \mathrm{mg} / \mathrm{dm}^{3}$ with 0.07 $\mathrm{mg} / \mathrm{dm}^{3}$ falling between the lowest and highest concentration during the dry season. During the rainy season, the concentration of $\mathrm{Hg}$ spread from not detected (well water and tap water) to $0.14 \mathrm{mg} / \mathrm{dm}^{3}$ with $0.003 \mathrm{mg} / \mathrm{dm}^{3}$ (borehole) and $0.09 \mathrm{mg} / \mathrm{dm}^{3}$ fell in between the observed extreme concentration levels. The concentrations of $\mathrm{Hg}$ were not detected in the water samples from tap water and well water in all the seasons. The concentration of $\mathrm{Hg}$ was detected only during the rainy season in borehole water sample which was below WHO and NSDWQ limits. However, the concentrations of $\mathrm{Hg}$ in the underground mining site and mining pond were above WHO limit of $0.006 \mathrm{mg} / \mathrm{dm}^{3}$ and NSDWQ limits of $0.001 \mathrm{mg} / \mathrm{dm}^{3}$ in both the seasons, which indicates contamination of water from underground mining site and mining pond water samples. $\mathrm{Hg}$ and its compounds affect the neurological system, causing irritation, memory issues, and loss of hearing or vision [23].

The concentration of manganese $(\mathrm{Mn})$ ranged from $0.12 \mathrm{mg} / \mathrm{dm}^{3}$ (well water) to $0.66 \mathrm{mg} / \mathrm{dm}^{3}$ (underground mining site), with $0.14 \mathrm{mg} / \mathrm{dm}^{3}$ (tap water), $0.30 \mathrm{mg} / \mathrm{dm}^{3}$ (borehole) and $0.50 \mathrm{mg} / \mathrm{dm}^{3}$ (mining pond) falling between the lowest and highest observed values during the dry season. During the rainy season, the concentration of Mn spread from $0.16 \mathrm{mg} / \mathrm{dm}^{3}$ (well water) to $0.92 \mathrm{mg} / \mathrm{dm}^{3}$ (underground mining site). The Mn concentrations of $0.17 \mathrm{mg} / \mathrm{dm}^{3}$ (tap water), $0.49 \mathrm{mg} / \mathrm{dm}^{3}$ (borehole) and $0.73 \mathrm{mg} / \mathrm{dm}^{3}$ (mining pond) lied in between the lowest and highest observed concentration levels. The highest concentrations of $\mathrm{Mn}$ $\left(0.92 \mathrm{mg} / \mathrm{dm}^{3}\right)$ were obtained in underground mining site during the rainy season while the lowest value of $0.12 \mathrm{mg} / \mathrm{dm}^{3}$ was found in well water sample. High concentration of $\mathrm{Mn}$ especially in the rainy season might be attributed to the dissolution of manganese from the chalcopyrite and siderite ores which underlie the area. It has 
been established that $\mathrm{Mn}^{2+}$ predominates in most groundwater at $\mathrm{pH}$ of 4.00-7.00 but may become oxidized under alkaline conditions at $\mathrm{pH}>8.00$ [23]. The concentrations of Mn were above WHO and NSDWQ in all sampling stations with the exception of well water and tap water samples. This demonstrated that $60 \%$ of water samples analyzed were contamination by $\mathrm{Mn}$.

The concentration of lead $(\mathrm{Pb})$ ranged from $0.003 \mathrm{mg} / \mathrm{dm}^{3}$ (well water) to $0.08 \mathrm{mg} / \mathrm{dm}^{3}$ (mining pond), with $0.007 \mathrm{mg} / \mathrm{dm}^{3}$ (tap water), $0.04 \mathrm{mg} / \mathrm{dm}^{3}$ (borehole) and $0.06 \mathrm{mg} / \mathrm{dm}^{3}$ (underground mining site) falling between the lowest and highest observed concentrations of $\mathrm{Pb}$ during the dry season. During the rainy season, the concentration of $\mathrm{Pb}$ ranged from $0.007 \mathrm{mg} / \mathrm{dm}^{3}$ (well water) to $0.10 \mathrm{mg} / \mathrm{dm}^{3}$ (mining pond). The $\mathrm{Pb}$ concentrations of $0.03 \mathrm{mg} / \mathrm{dm}^{3}$ (tap water), $0.06 \mathrm{mg} / \mathrm{dm}^{3}$ (borehole) and $0.09 \mathrm{mg} / \mathrm{dm}^{3}$ (underground mining site) fell in between the lowest and highest observed concentrations. The highest concentration of $\mathrm{Pb}$ was detected in the mining pond water samples during the rainy season while the lowest was recorded in well water samples during the dry season. The concentrations of $\mathrm{Pb}$ in all sampling sites were above the desirable limit except for well water, where the $\mathrm{Pb}$ concentrations were below the desirable limit in all the seasons and tap water during the dry season. Higher concentration of $\mathrm{Pb}$ in almost all samples analyzed is indicating that the groundwater in the study area was contamination by $\mathrm{Pb}$. Davies et al. [27] established that the high concentration of $\mathrm{Pb}$ in groundwater of mining sites can be linked to the high immobility of $\mathrm{Pb}$ especially, at a low $\mathrm{pH}$. $\mathrm{Pb}$ is a highly toxic metal whose widespread uses has caused extensive environmental degradation and health problems in many parts of the world.

The concentrations of zinc $(\mathrm{Zn})$ ranged from $2.29 \mathrm{mg} / \mathrm{dm}^{3}$ (well water) to $17.43 \mathrm{mg} / \mathrm{dm}^{3}$ (mining pond) with $4.88 \mathrm{mg} / \mathrm{dm}^{3}$ (borehole), $5.26 \mathrm{mg} / \mathrm{dm}^{3}$ (tap water) and $11.73 \mathrm{mg} / \mathrm{dm}^{3}$ (underground mining site) falling between the observed extreme concentrations during the dry season. During the rainy season, the concentrations of $\mathrm{Zn}$ ranged from $2.85 \mathrm{mg} / \mathrm{dm}^{3}$ (well water) to $20.00 \mathrm{mg} / \mathrm{dm}^{3}$ (mining pond), with $5.90 \mathrm{mg} / \mathrm{dm}^{3}$ (borehole), $7.01 \mathrm{mg} / \mathrm{dm}^{3}$ (tap water) and $14.05 \mathrm{mg} / \mathrm{dm}^{3}$ (underground mining site) falling in between the lowest and highest observed concentrations of $\mathrm{Zn}$. The concentration of $\mathrm{Zn}$ in all sampling locations exceeded the desirable limit of $3.00 \mathrm{mg} / \mathrm{dm}^{3}$ recommended by NSDWQ in both seasons. The highest $\mathrm{Zn}$ concentrations of $20.00 \mathrm{mg} / \mathrm{dm}^{3}$ was found in the mining pond water (RGW3) during rainy seasons, while the lowest $\left(2.29 \mathrm{mg} / \mathrm{dm}^{3}\right)$ was observed in well water samples during the dry season. This indicated that $100 \%$ of groundwater samples analyzed were contaminated by $\mathrm{Zn}$. Previous studies had established that mining areas are well characterized by high concentration of heavy metals resulted from mine tailings and mine waste [5]. The observed high values of $\mathrm{Zn}$ might be associated with the phenomenon of leaching due to heavy metals precipitation from the overburden dumps and tailing ponds [1]. $\mathrm{Zn}$ is an important metal required for optimal growth and development; but, in higher concentrations, it is poisonous [28]. The toxicity of $\mathrm{Zn}$ in human may occur if zinc concentration reaches $3 \mathrm{mg} / \mathrm{dm}^{3}$ in water. The toxicity is characterized by symptoms of irritability, muscular stiffness and pain, loss of appetite and nausea [29].
3. Seasonal variations of heavy metals and some physical parameters of the groundwater samples

Heavy metals and physical characteristics of water samples showed marked seasonal variations as shown in Tables I and II, with the highest concentrations recorded during the rainy season and lower concentrations reported during the dry season. High concentrations of heavy metals and some physical parameters in the rainy season might be due to the rainfall during the rainy season which not only dilutes the heavy metals but also helps in their leaching [30]. However, independent statistical t-test revealed no statistically significant difference between the means of two seasons in all the groundwater samples analyzed.

\section{CONCLUSION}

The findings of this study revealed that the mean concentrations of $\mathrm{As}, \mathrm{Cd}, \mathrm{Cr}, \mathrm{Hg}, \mathrm{Mn}, \mathrm{Pb}, \mathrm{Zn}$ and some physical parameters $(\mathrm{pH}, \mathrm{EC}$ and TDS) varied with the sampling sites, with higher values reported during the rainy season. The $\mathrm{pH}, \mathrm{EC}$ and TDS were within the desirable limits recommended by WHO (2011) and NSDWQ (2007) in all sampling locations except for underground mining sites (RGW1) and mining pond (RGW3) samples during dry and rainy seasons. While the mean concentrations of all the heavy metals were above the desirable limits recommended by WHO and NSDWQ during both seasons except in well water (RGW5) samples and few locations where the heavy metals were not detected. The study demonstrates heavy metal contamination of the groundwater of Riruwai mining area, and it is suggested that water resources in the area should be carefully monitored, and more efforts should be made to reduce heavy metal concentrations, particularly $\mathrm{As}, \mathrm{Cd}, \mathrm{Cr}$, and $\mathrm{Zn}$, in the area.

\section{REFERENCES}

[1] Singh, G. and Kamal, R.K (2017). Heavy Metal Contamination and its Indexing Approach for Groundwater of Goa Mining Region, India. Applied Water Science, 7:1479-1485.

[2] Li, R. and Merchant, J.W. (2013). Modeling Vulnerability of Groundwater to Pollution under Future Scenarios of Climate Change and Biofuels-related Land Use Change: A Case Study in North Dakota, USA. Science of the Total Environment, 447:32-45.

[3] Arulbalaji, P., Padmalal, D. and Sreelash, K. (2019). GIS and AHP Techniques Based Delineation of Groundwater Potential Zones: A Case Study from Southern Western Ghats, India. Scientific Reports, 9:2082.

[4] Nouri, J., Khorasani, N., Lorestani, B., Youse fi, N., Hassani, A.H. and Karami, M. (2009). Accumulation of Heavy Metals in Soil and Uptake by Plant Species with Phytoremediation Potential. Environmental Earth Sciences, 59(2):315-323.

[5] Tiwari, A.K., Singh, P.K., Singh, A.K. and De Maio, M. (2016) Estimation of Heavy Metal Contamination in Groundwater and Development of a Heavy Metal Pollution Index by Using GIS Technique. Bulletin of Environmental Contamination and Toxicology, 96:508-515.

[6] Bessa, A.Z.E., Ngueutchoua, G. and Ndjigui, P.D. (2018). Mineralogy and geochemistry of sediments from Simbock Lake, Yaounde area (southern Cameroon): provenance and environmental implications Arabian Journal of Geoscience, 11 (22):710.

[7] Adaikpoh, E.O., Nwajei, G.E and Ogala, J.E. (2005). Heavy metals concentrations in coal and sediments from river Ekulu in Enugu, Coa City of Nigeria. Journal of Applied Sciences and Environmental Management, 9(3):5-8.

[8] Giri, S and Singh, A.K. (2019). Assessment of metal pollution in groundwater using a novel multivariate metal pollution index in the 
mining areas of the Singhbhum copper belt. Environmental Earth Sciences, 78:192. doi: 10.1007/s12665-019-8200-9.

[9] Okegye, J.I and Gajere, J.N. (2015). Assessment of Heavy Metal Contamination in Surface and Ground Water Resources around Udege Mbeki Mining District, North-Central Nigeria. Journal of Geology and Geophysics, 4:203. doi:10.4172/2329-6755.1000203.

[10] Dhakate, R., Singh, V.S. and Hodlur, G.K. (2008). Impact Assessment of Chromite Mining on Groundwater through Simulation Modeling Study in Sukinda Chromite Mining Area, Orissa, India. Journal of Hazardous Materials, 160:535-547.

[11] Alhaji, M., Adamu, S. and Buba, L.F. (2017). Assessment of Summer Heat Stress Condition for Tourism Development in Riruwai Ring Complex, Doguwa Local Government, Kano State, Dutse Journal of Pure and Applied Sciences, 3 (2): 288-299.

[12] Olasehinde, A., Ashano, E.C. and Singh, G.P. (2012). Analysis of Magnetic Anomaly over the Riruwai Younger Granite Ring Complex: A Geodynamic Implication. Continental Journal of Earth Sciences, 7 (1): $9-18$.

[13] Bravo, A.G., Kothawala, D.N., Attermeyer, K., Tessier, E., Bodmer, P. and Amouroux, D. (2018). Cleaning and Sampling Protocol for Analysis of Mercury and Dissolved Organic Matter in Freshwater Systems. Methods X, 5:1017-1026.

[14] APHA (1998). "Standard Methods for the Examination of Water and Wastewater" (21st ed). APHA-AWWA-WEF, Washington, D. C, U.S.A.

[15] Silas, I.I., Wuana, R.A, Augustine, A. U. (2018). Seasonal Variation in Water Quality Parameters of River Mkomon Kwande Local Government Area, Nigeria. International Journal of Recent Research in Physics and Chemical Sciences (IJRRPCS), 5(1):42-62.

[16] Akpan, A.W. (2004): The Water Quality of Some Tropical Fresh Water Bodies in Uyo (Nigeria) Receiving Municipal Effluents, Slaughterhouse Washings and Agricultural Land Drainage. The Environmentalist, 24:49-50.

[17] Rahman, M.A.T.M., Paul, M., Bhoumik, N., Hassan, M., Alam, M.D.K. and Aktar, Z. (2020). Heavy Metal Pollution Assessment in the Groundwater of the Meghna Ghat Industrial Area, Bangladesh, by Using Water Pollution Indices Approach. Applied Water Science, 10:186.

[18] Boularbah, A., Schwartz, C., Bitton, G. and Morel, J. L. (2006). Heavy Metal Contamination from Mining Sites in South Morocco: Use of a Biotest to Assess Metal Toxicity of Tailings and Soils. Chemosphere, 63: 802-810.
[19] Ravikumar, P. and Somashekar, R.K. (2017). Principal Component Analysis and Hydrochemical Facies Characterization to Evaluate Groundwater Quality in Varahi Riverbasin, Karnataka State, India. Applied Water Science, 7:745-755.

[20] Antony, S., Dev, V.V., Kaliraj, S., Ambili, M.S. and Krishnan, K.A (2020). Seasonal Variability of Groundwater Quality in Coastal Aquifers of Kavaratti Island, Lakshadweep Archipelago, India. Groundwater for Sustainable Development, 11:100377.

[21] Abida, B. and Harikrishna, (2008), Study on the Quality of Water in Some Streams of Cauvery River. Journal of Chemistry, 5(2): 377-384.

[22] Zhu, G., Wu, X., Ge, J., Liu, F., Zhao, W. and Wu, C. (2020). Influence of Mining Activities on Groundwater Hydrochemistry and Heavy Metal Migration Using a Self-Organizing Map (SOM). Journal of Cleaner Production, 257:120664.

[23] Obasi, P.N and Akudinobi, B.B. (2020). Potential Health Risk and Levels of Heavy Metals in Water Resources of Lead-Zinc Mining Communities of Abakaliki, Southeast Nigeria. Applied Water Science, $10,184$.

[24] Agency for Toxic Substances and Disease Registry (ATSDR) (2007) U.S. Department of Health and Human Services, Public Health Service, Division of Toxicology 1600, Atlanta, GA 30333.

[25] Prasad, B., Kumari, P., Bano, S. and Kumari, S. (2014). Ground Water Quality Evaluation near Mining Area and Development of Heavy Metal Pollution Index. Applied Water Science, 4:11-17.

[26] Engwa. G.A., Ferdinand, P.U., Nwalo. F.N., Unachukwu, M.N (2018). "Mechanism and effects of heavy metal toxicity in humans, poisoning in the modern world-new tricks for an old dog"? Intech Open, USA.

[27] Davies, B.E, Bowman, C., Davies, T.C. and Sellinus, O. (2005). "Medical Geology: Perspectives and Prospects. Essential of Medical Geology". Elsevier Inc. Amsterdam. Pp. 1-14.

[28] Ayub, A. and Ahmad, S.S. (2020). Seasonal Assessment of Groundwater Contamination in Coal Mining Areas of Balochistan. Sustainability, 12: 6889.

[29] Fergusson. I.E (1990). "The heavy elements chemistry, environmental impact and health effects". Pergamon press, New York.

[30] Gupta, S.K. and Nikhil, K. (2016). Ground Water Contamination in Coal Mining Areas: A Critical Review. International Journal of Engineering and Applied Sciences, 3(2): 69-74. 